Tournal of Electranc Materials SAND $98-2591 \mathrm{~J}$.

\title{
REDISTRIBUTION OF IMPLANTED DOPANTS IN GaN
}

X. A. Cao ${ }^{(1)}$, R. G. Wilson ${ }^{(2)}$, J. C. Zolper ${ }^{(3)}$, S. J. Pearton ${ }^{(1)}$, J. Han ${ }^{(4)}$, R. J. Shul ${ }^{(4)}$, D. J. Rieger ${ }^{(4)}$, R. K. Singh! ${ }^{(1)}$ M. Fu ${ }^{(5)}$, V. Scarvepalli ${ }^{(5)}$, J. A. Sekhar $^{(5)}$, and J. M. Zavada ${ }^{(6)}$

(1) Department of Materials Science and Engineering, University of Florida, Gainesville, FL 32611 USA.

(2) Consultant, Stevenson Ranch, CA 91381 USA

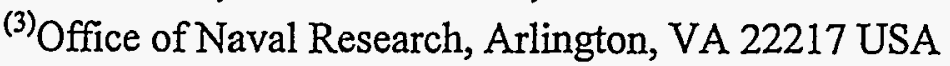

${ }^{(4)}$ Sandia National Laboratories, Albuquerque, NM 87185 USA

(5) Micropyretics Heaters International, Inc. Cincinnati, OH 45212 USA

${ }^{(6)}$ European Research Office, USARDSG, London, England

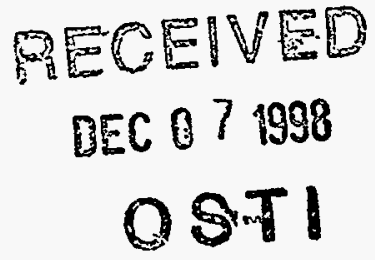

\section{ABSTRACT}

Donor ( $\mathrm{S}, \mathrm{Se}$ and $\mathrm{Te})$ and acceptor $(\mathrm{Mg}, \mathrm{Be}$ and $\mathrm{C})$ dopants have been implanted into $\mathrm{GaN}$ at doses of $3-5 \times 10^{14} \mathrm{~cm}^{-2}$ and annealed at temperatures up to $1450{ }^{\circ} \mathrm{C}$. No redistribution of any of the elements is detectable by Secondary Ion Mass Spectrometry, except for $\mathrm{Be}$, which displays an apparent damage-assisted diffusion at $900^{\circ} \mathrm{C}$. At higher temperatures there is no further movement of the Be, suggesting that the point defect flux that assists motion at lower temperatures has been annealed. Effective diffusivities are $\leq 2 \times 10^{-13} \mathrm{~cm}^{2} \cdot \sec ^{-1}$ at $1450^{\circ} \mathrm{C}$ for each of the dopants in $\mathrm{GaN}$. 


\section{Introduction}

Ion implantation is an effective technology for selected-area doping or isolation of GaN-based devices. As reviewed previously by Zolper, ${ }^{(1)}$ implantation of donors at high dose $\left(>5 \times 10^{14} \mathrm{~cm}^{-2}\right)$ can be used to decrease source and drain access resistance in field effect transistors(FETs), at lower doses to create channel regions for FETs, while sequential implantation of both acceptors and donors may be used to fabricate $\mathrm{p}-\mathrm{n}$ junctions. Two different device structures have been demonstrated using the latter method, namely a junction field-effect transistor ${ }^{(2)}$ and a planar, homojunction lightemitting diode(LED). ${ }^{(3)}$

Due to the high vapor pressure of $\mathrm{N}_{2}$ above $\mathrm{GaN}$ at the temperatures needed to activate implanted dopants, ${ }^{(4)}$ it has proven necessary to either provide an overpressure of several kbars of $\mathrm{N}_{2}$, ${ }^{(5)}$ or to employ an AlN layer as an encapsulant during annealing. ${ }^{(6)}$ The amount of residual lattice damage in the implanted $\mathrm{GaN}$ after annealing is a function of ion dose - for the relatively high doses needed for source/drain doping, it has been shown previously that annealing temperatures of $\geq 1400^{\circ} \mathrm{C}$ are desirable..$^{(7-12)}$ We have found that $\mathrm{Si}$, the most common n-type dopant, shows no detectable redistribution at $1400{ }^{\circ} \mathrm{C}$, and that annealing at this temperature produces activation percentages of $\geq 90 \% .{ }^{(13)}$ Annealing at $1500{ }^{\circ} \mathrm{C}$ led to a reduction in both sheet electron concentration and electron mobility, which is consistent with self-compensation through site-switching of the Si. There is no available information on the other donor species, or on the possible acceptor dopants, in terms of their redistribution during ultra-high temperature annealing. In this paper we report on a Secondary Ion Mass Spectrometry (SIMS) study of GaN implanted with the group VI donors, $\mathrm{S}, \mathrm{Se}$ and $\mathrm{Te}$, and the acceptor species $\mathrm{Mg}, \mathrm{Be}$ and 


\section{DISCLAIMER}

This report was prepared as an account of work sponsored by an agency of the United States Government. Neither the United States Government nor any agency thereof, nor any of their employees, make any warranty, express or implied, or assumes any legal liability or responsibility for the accuracy, completeness, or usefulness of any information, apparatus, product, or process disclosed, or represents that its use would not infringe privately owned rights. Reference herein to any specific commercial product, process, or service by trade name, trademark, manufacturer, or otherwise does not necessarily constitute or imply its endorsement, recommendation, or favoring by the United States Government or any agency thereof. The views and opinions of authors expressed herein do not necessarily state or reflect those of the United States Government or any agency thereof. 


\section{DISCLAIMER}

Portions of this document may be illegible in electronic image products. Images are produced from the best available original document. 
C. Only Be is found to show redistribution during annealing, emphasizing the extremely good high temperature stability of dopants in $\mathrm{GaN}$.

\section{Experimental}

Layers of $\mathrm{GaN} 2-3 \mu \mathrm{m}$ thick were grown at $\sim 1040{ }^{\circ} \mathrm{C}$ on c-plane $\mathrm{Al}_{2} \mathrm{O}_{3}$ by atmospheric pressure Metal Organic Chemical Vapor Deposition(MOCVD), using triethylgallium and ammonia. From $\mathrm{x}$-ray diffraction and photoluminescence measurements we know this material is typical of the current state-of-the-art heteroepitaxial GaN.

The samples were implanted at $25^{\circ} \mathrm{C}$ with $150 \mathrm{keV}^{24} \mathrm{Mg}^{+}, 80 \mathrm{keV}{ }^{9} \mathrm{Be}^{+}, 80 \mathrm{keV}^{12} \mathrm{C}^{+}$, $200 \mathrm{keV}^{32} \mathrm{~S}^{+}, 300 \mathrm{keV}{ }^{80} \mathrm{Se}^{+}$, or $600 \mathrm{keV}{ }^{128} \mathrm{Te}^{+}$ions, at doses of $3-5 \times 10^{14} \mathrm{~cm}^{-2}$. This puts the projected range, $R_{p}$, of the implanted species at least $1500 \AA$ into the GaN in all cases, avoiding effects due to near-surface point defect injection. The samples were capped with $\sim 1000 \AA$ of reactively sputtered AIN, and annealed at temperatures of 1200 $1450^{\circ} \mathrm{C}$ under a $\mathrm{N}_{2}$ ambient in the Zapper ${ }^{\mathrm{TM}}$ furnace described previously. ${ }^{(14)}$ The dwell time at the peak temperature was $\sim 10 \mathrm{sec}$. After annealing, the AlN was selectively etched in aqueous $\mathrm{KOH}$ at $80^{\circ} \mathrm{C} .{ }^{(15)}$ The atomic distributions before and after annealing were measured by SIMS, and the data quantified using the as-implanted sample as a standard.

\section{Results and Discussion}

(a) Acceptor dopants

Figure 1 shows SIMS profile of implanted $\mathrm{Mg}$ in $\mathrm{GaN}$, both before and after annealing at $1450^{\circ} \mathrm{C}$. Within the resolution of SIMS $(\sim 200 \AA$ under these conditions) 
there is no motion of the Mg. Using a simple $2 \sqrt{D t}$ estimation of the diffusivity at this temperature gives a value of $\leq 2 \times 10^{-13} \mathrm{~cm}^{2} \cdot \mathrm{sec}^{-1}$. This is in sharp contrast to its behavior in $\mathrm{GaAs},{ }^{(16-18)}$ where the rapid diffusion of the Ga-site acceptors during annealing can only be suppressed by co-implanting a group $\mathrm{V}$ element to create a sufficient number of vacant sites for the initially interstitial acceptor ions to occupy upon annealing. This reduces the effective diffusivity of the acceptor and increases its electrical activation. The additional advantage gained from using a group $\mathrm{V}$ co-implant is that it maximizes occupation of the group III site by the acceptor. ${ }^{(19)}$ In addition, implanted $\mathrm{Mg}$ in GaAs often displays outdiffusion toward the surface (in most case up, rather than down, the concentration gradient), leading to loss of dopant into the annealing cap. ${ }^{(20)}$ This has been suggested to be due to non-equilibrium levels of $\mathrm{Ga}$ interstitials created by the implantation process. This mechanism is clearly absent for implanted $\mathrm{Mg}$ in GaN.

Figure 2 shows a series of profiles for ${ }^{9} \mathrm{Be}$ before and after annealing up to $1200^{\circ} \mathrm{C}$. Note that there is an initial broadening of the profile at $900{ }^{\circ} \mathrm{C}$, corresponding to an effective diffusivity of $-5 \times 10^{-13} \mathrm{~cm}^{2} \cdot \mathrm{s}^{-1}$ at this temperature. However there is no subsequent redistribution at temperatures up to $1200^{\circ} \mathrm{C}$. Implanted Be shows several types of anomalous diffusion in GaAs, including up-hill diffusion and movement in the tail of the profile, in addition to normal concentration-dependent diffusion, ${ }^{(18)}$ which also result from the non-equilibrium concentrations of point defects created by the nuclear stopping process of the implanted ions. It appears that in $\mathrm{GaN}$, the interstitial $\mathrm{Be}$ undergoes a type of transient-enhanced diffusion until these excess point defects are removed by annealing, at which stage the Be is basically immobile.

Carbon is typically a very slow diffuser in all III-V compounds, since it strongly prefers substitutional lattice sites. ${ }^{(18-21)}$ In $\mathrm{GaN}$ it has been shown that it is possible to get 
p-type conductivity in carbon-doped material, albeit with low hole concentrations. ${ }^{(22)}$ In general however, GaN containing high concentrations of carbon is self-compensated, suggesting that carbon is occupying both $\mathrm{Ga}$ and $\mathrm{N}$ sites. Figure 3 shows that it is an extremely slow diffuser when implanied into $\mathrm{GaN}$, with $\mathrm{D}_{\text {eff }} \leq 2 \times 10^{-13} \mathrm{~cm} \cdot \mathrm{sec}^{-1}$ at 1400 ${ }^{\circ} \mathrm{C}$.

(b) Donor dopants

Our previous results showed that $\mathrm{Si}$ is an effective donor impurity in implanted $\mathrm{GaN} .{ }^{(13)}$ Little work has been performed on the group VI donors, although Feng et al. ${ }^{(23)}$ showed that Se displayed relatively high diffusion during growth by MOCVD at 1000 ${ }^{\circ} \mathrm{C}$. Wilson reported some redistribution of implanted $\mathrm{S}$ after annealing at $700-1000{ }^{\circ} \mathrm{C}$ in relatively thin layers of $\mathrm{GaN}_{,}^{(24)}$ which might have been influenced by the high crystalline defect density in the material.

Figure 4 shows SIMS profiles before and after $1450^{\circ} \mathrm{C}$ annealing of implanted $\mathrm{S}$ in GaN. There is clearly no motion of the sulfur under these conditions, which suggests that, as expected, the structural quality of the GaN may have a strong influence on the apparent diffusivity of dopants. The samples in the present experiment are much thicker than those employed in the previous work, ${ }^{(24)}$ and the extended defect density will be correspondingly lower in the implanted region $\left(\sim 5 \times 10^{8} \mathrm{~cm}^{-2}\right.$ compared to $\sim 10^{10} \mathrm{~cm}^{-2}$ in the thin samples).

The other group VI donors, $\mathrm{Se}$ and $\mathrm{Te}$, have low diffusion coefficients in all compound semiconductors (for example $D_{\mathrm{Se}}=5 \times 10^{-15} \mathrm{~cm}^{2} \cdot \sec ^{-1}$ at $850{ }^{\circ} \mathrm{C}$ in $\mathrm{GaAs}$ ), ${ }^{(18,19)}$ and we find a similar result for these species implanted into GaN. Figure 5 shows the 
SIMS profiles before and after $1450^{\circ} \mathrm{C}$ annealing for Se, while Figure 6 shows similar data for Te. In both cases the effective diffusivity at this temperature is $\leq 2 \times 10^{-13} \mathrm{~cm}^{2} \cdot \mathrm{sec}^{-1}$.

\section{Summary and Conclusions}

Most of the common acceptor and donor species have been implanted into $\mathrm{GaN}$ at room temperature, and subsequently annealed up to $1450^{\circ} \mathrm{C}$. With the exception of $\mathrm{Be}$, which shows an apparent damage-assisted redistribution at $900^{\circ} \mathrm{C}$, none of the species show detectable motion under these conditions. This bodes well for the fabrication of GaN-based power devices such as thyristors and insulated gate bipolar transistors which will require creation of doped well or source/drain regions by implantation. The low diffusivities of implanted dopants in $\mathrm{GaN}$ means that junction placement should be quite precise and there will be less problems with lateral diffusion of the source/drain regions towards the gate. Finally, the results show the effectiveness of the AIN cap in protecting the GaN surface from dissociation, since if any of the surface was degraded during annealing, the implant profiles would no longer overlap.

\section{ACKNOWLEDGEMENTS}

The work of UF is partially supported by a DARPA/EPRI grant MDA 972-98-1-0006 (E. R. Brown/J. Melcher) and by an NSF grant DMR 9732865 (L. Hess). Sandia is a multiprogram laboratory operated by Sandia Corporation, a Lockheed-Martin company, for the US Department of Energy under contract No. DEAC04-94 AL 85000. The work of R. G. Wilson is partially supported by an ARO grant. 


\section{References}

1. J. C. Zolper, in GaN and Related Materials, Vol. 2 of Optoelectronic Properties of Semiconductors and Superlattices. (Gordon and Breach, NY 1997); J. C. Zolper, S. J. Pearton, C. R. Abernathy, C. B. Vartuli, C. Yuan and R. A. Stall, Proc. Vol. 95-21 (Electrochemical Society, Pennington, NJ, 1995), pp 144-151; J. C. Zolper and R. J. Shul, MRS Bulletin 2236 (1997); J. C. Zolper, Proc. Vol. $97-34$ (Electrochemical Society, Pennington, NJ, 1997), pp 76-82; J. C. Zolper, R. J. Shul, A. G. Baca, S. J. Pearton, C. R. Abernathy, R. G. Wilson, R. A. Stall and M. Shur, Proc. Vol. $\underline{96-11}$ (Electrochemical Society, Pennington, NJ, 1996), pp 149-158; J. C. Zolper, J. Cryst. Growth $\underline{178} 175$ (1997).

2. J. C. Zolper, R. J. Shul, A. G. Baca, R. G. Wilson, S. J. Pearton and R. A. Stall, Appl. Phys. Lett. 682273 (1996).

3. H. P. Maruska, M. Lioubtchenko, T. G. Tetreault, M. Osinski, S. J. Pearton, M. Schurman, R. Vaudo, S. Sakai, Q. Chen and R. J. Shul, Mat. Res. Soc. Symp. Proc. 483345 (1998).

4. See for example, N. Newman, Proc. Vol. $\underline{96-11}$ (Electrochemical Society, Pennington, NJ, 1996), pp 1-19; S. Porowski and I. Grzegory, in GaN and Related Materials, Vol. 2 of Optoelectronic Properties of Semiconductors and Superlattices (Gordon and Breach, NY 1997); T. Matsuoka, T. Sasaki and A. Katsui, Optoelectronics $\underline{5} 53$ (1990).

5. J. C. Zolper, J. Han, S. B. Van Deusen, R. M. Biefeld, M. H. Crawford, J. Han, T. Suski, J. M. Baranowski and S. J. Pearton, Mat. Res. Soc. Symp. Proc. 482609 (1998). 
6. J. C. Zolper, D. J. Reiger, A. G. Baca, S. J. Pearton, J. W. Lee and R. A. Stall, Appl. Phys. Lett. $\underline{69} 538$ (1996).

7. J. C. Zolper, J. Han, R. M. Biefeld, S. B. Van Deusen, W. R. Wampler, D. J. Reiger, S. J. Pearton, J. S. Williams, H. H. Tan and R. Stall, J. Electron. Mater. 27179 (1998).

8. H. H. Tan, J. S. Williams, J. Zou, D. J. H. Cockayne, S. J. Pearton and R. A. Stall, Appl. Phys. Lett. $\underline{69} 2364$ (1996).

9. J. C. Zolper, M. H. Crawford, H. H. Tan, J. S. Williams, J. Zou, D. J. H. Cockayne, S. J. Pearton and R. F. Karlicek, Appl. Phys. Lett. 702729 (1997).

10. C. Liu, B. Mecnsching, M. Zeitter, K. Volz and B. Rauschenbach, Phys. Rev. B 57 217 (1997).

11. S. Strite, A. Pelzman, T. Suski, M. Leszczynski, J. Jun, A. Rockett; M. Kemp and K. J. Ebeling, Int. J. Nitride Semicond. Res. 217 (1997).

12. T. Suski, J. Jun, M. Leszczynski, H. Teisseyre, I. Grzegory, S. Porowski, J. M. Baranowski, A. Rockett, S. Strite, A. Stonert, A. Turos, H. H. Tan, J. S. Williams and C. Jagadish, Mat. Res. Soc. Symp. 482817 (1998).

13. X. A. Cao, C. R. Abernathy, R. K. Singh, S. J. Pearton, M. Fu, V. Sarvepalli, J. A. Sekhar, J. C. Zolper, D. J. Rieger, J. Han, T. J. Drummond, R. J. Shul and R. G. Wilson, Appl. Phys. Lett. 73 (1998).

14. M. Fu, V. Sarvepalli, R. K. Singh, C. R. Abernathy, X. Cao, S. J. Pearton and J.'A, Sekhar, Mat. Res. Soc. Symp. Proc. 483345 (1998).

15. J. R. Mileham, S. J. Pearton, C. R. Abernathy, J. D. MacKenzie, R. J. Shul and S. P. Kilcoyne, Appl. Phys. Lett. 671119 (1995).

16. M. D. Deal and H. G. Robinson, Appl. Phys. Lett. 551990 (1989). 
17. H. G. Robinson, M. D. Deal and D. A. Stevenson, Appl. Phys. Lett. $\underline{58} 2000$ (1991).

18. M. D. Deal, C. J. Hu, C. C. Lee and H. G. Robinson, Mat. Res. Soc. Symp. $\underline{300} 365$ (1993).

19. S. J. Pearton, Int. J. Mod. Phys. $\underline{7} 4687$ (1993).

20. H. G. Robinson, M. D. Deal, P. B. Griffin, G. Amaratunga, P. B. Griffin, D. A. Stevenson and J. D. Plummer, J. Appl. Phys. 712615 (1992).

21. S. J. Pearton and C. R. Abernathy, Appl. Phys. Lett. $\underline{5} 678$ (1989).

22. C. R. Abernathy, J. D. MacKenzie, S. J. Pearton and W. S. Hobson, Appl. Phys. Lett. 661969 (1995).

23. M. S. Feng, J. D. Guo and G. C. Chi, Proc. Vol. 95-21 (Electrochemical Society, Pennington, NJ, 1995), pp 43-49.

24. R. G. Wilson, S. J. Pearton, C. R. Abernathy and J. M. Zavada. Appl. Phys. Lett. $\underline{6}$ 2238 (1995); R. G. Wilson, Proc. Vol. 95-21 (Electrochemical Society, Pennington, NJ, 1995), pp 152-162. 


\section{Figure Captions}

Figure 1. SIMS profiles before and after annealing at $1450{ }^{\circ} \mathrm{C}$ of implanted $\mathrm{Mg}(150$ $\left.\mathrm{keV}, 5 \times 10^{14} \mathrm{~cm}^{-2}\right)$ in $\mathrm{GaN}$.

Figure 2. SIMS profiles before and after annealing at different temperatures of implanted $\mathrm{Be}\left(80 \mathrm{keV}, 5 \times 10^{14} \mathrm{~cm}^{-2}\right)$ in $\mathrm{GaN}$.

Figure 3. SIMS profiles before and after annealing at $1400{ }^{\circ} \mathrm{C}$ of implanted $\mathrm{C}(80 \mathrm{keV}$, $\left.5 \times 10^{14} \mathrm{~cm}^{-2}\right)$ in $\mathrm{GaN}$.

Figure 4. SIMS profiles before and after annealing at $1450^{\circ} \mathrm{C}$ of implanted $\mathrm{S}(200 \mathrm{keV}$, $\left.5 \times 10^{14} \mathrm{~cm}^{-2}\right)$ in $\mathrm{GaN}$.

Figure 5. SIMS profiles before and after annealing at $1450^{\circ} \mathrm{C}$ of implanted $\mathrm{Se}(300 \mathrm{keV}$, $\left.5 \times 10^{14} \mathrm{~cm}^{-2}\right)$ in $\mathrm{GaN}$.

Figure 6. SIMS profiles before and after annealing at $1450{ }^{\circ} \mathrm{C}$ of implanted $\mathrm{Te}(600 \mathrm{keV}$, $3 \times 10^{14} \mathrm{~cm}^{-2}$ ) in $\mathrm{GaN}$. 


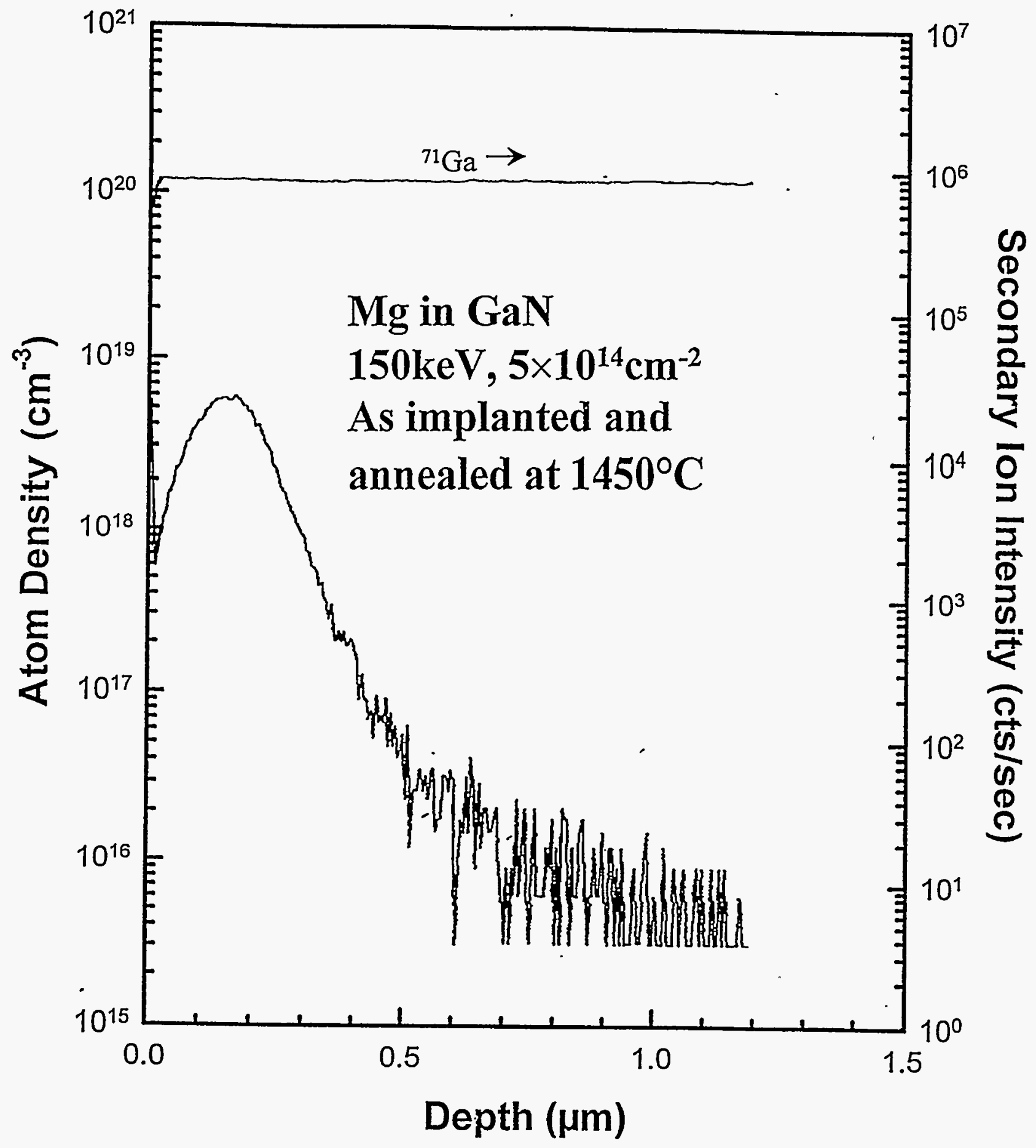




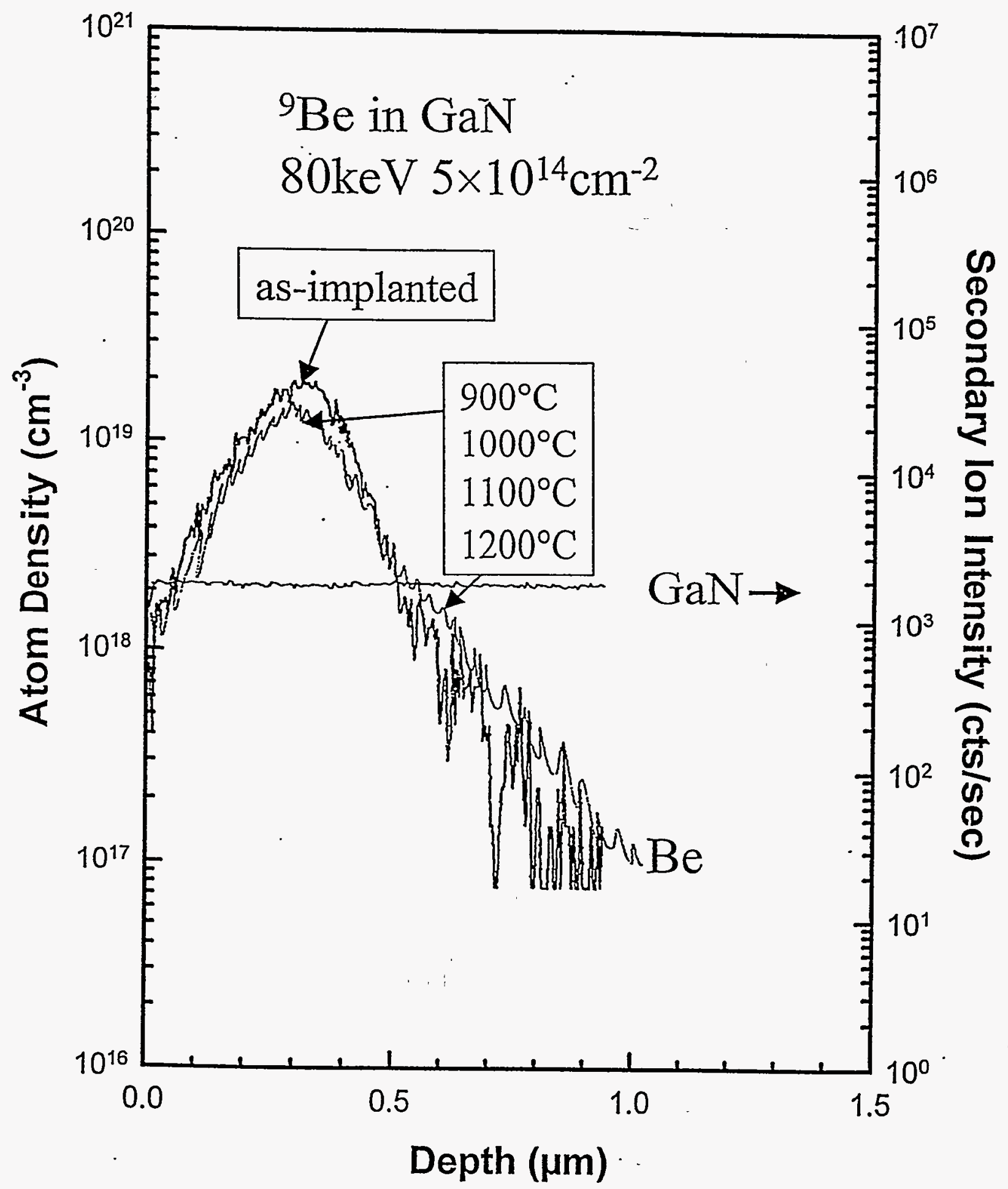




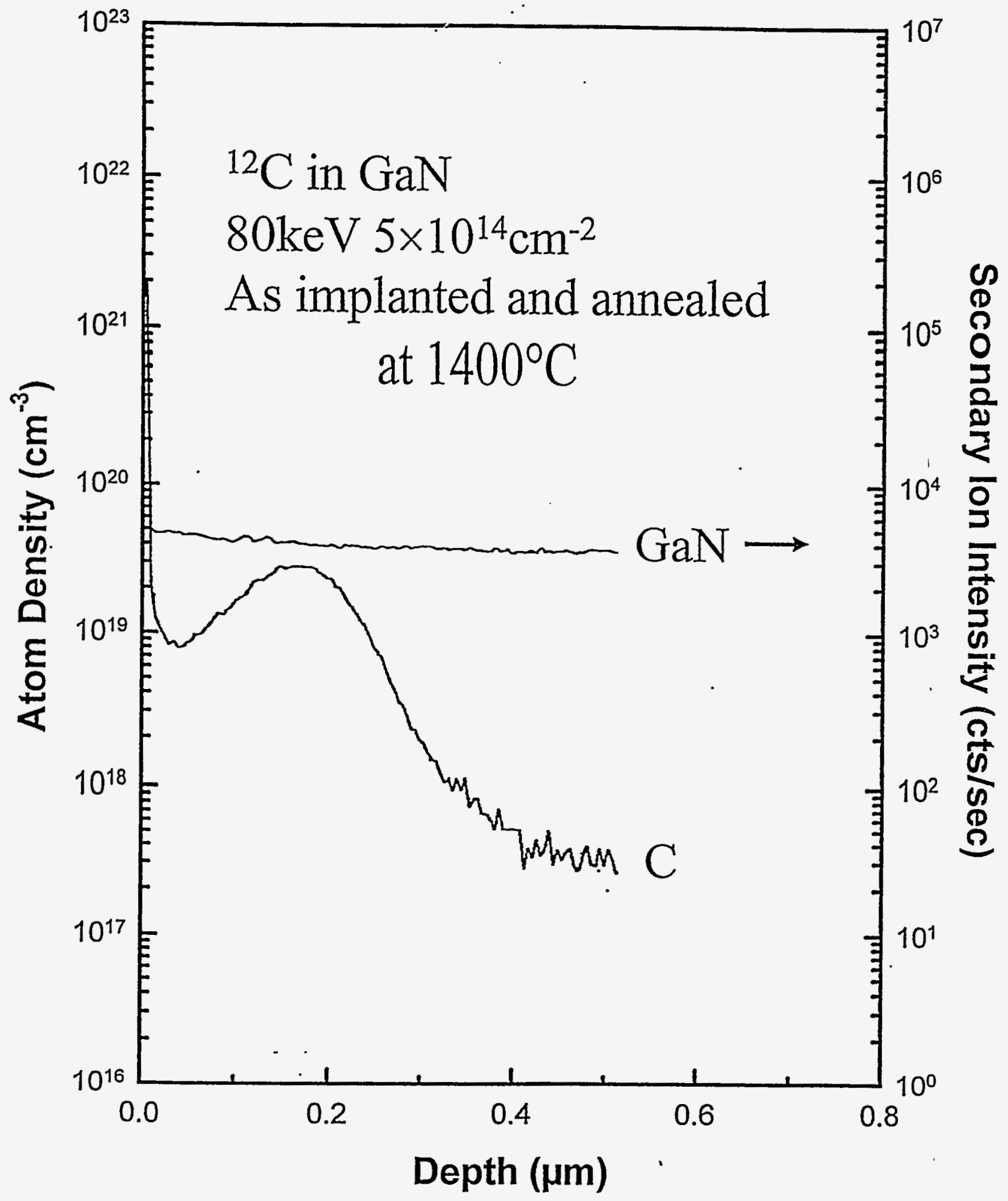




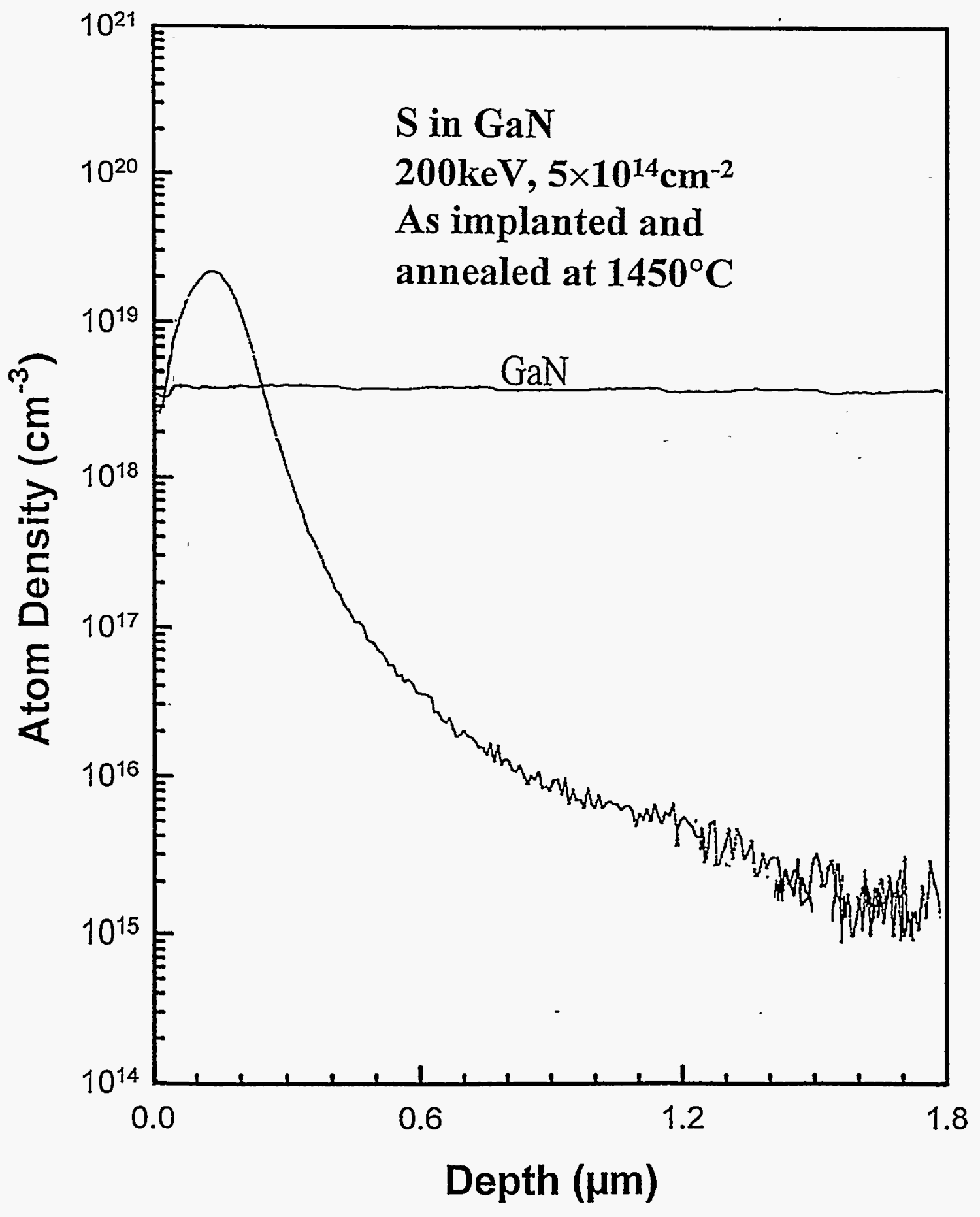




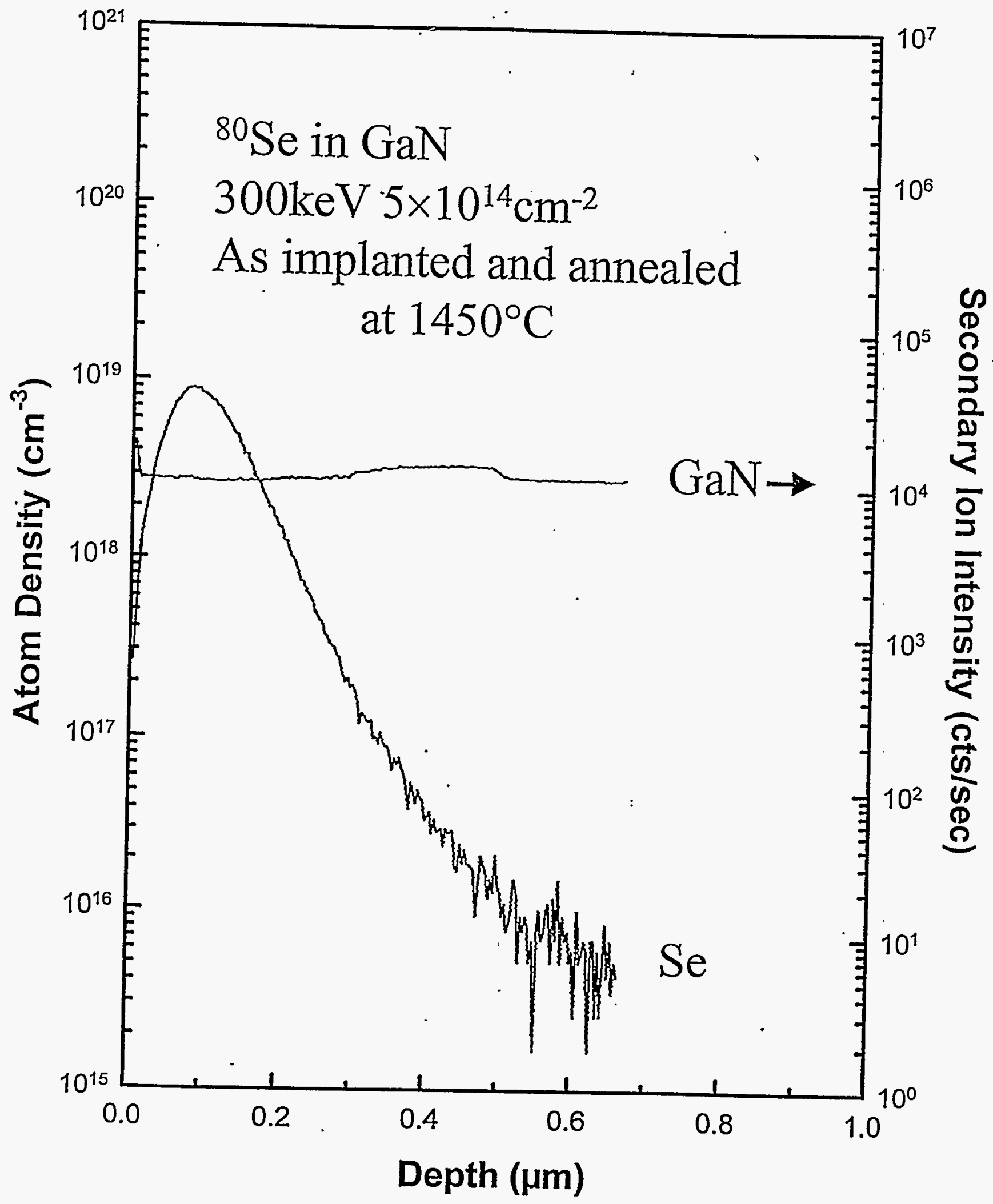




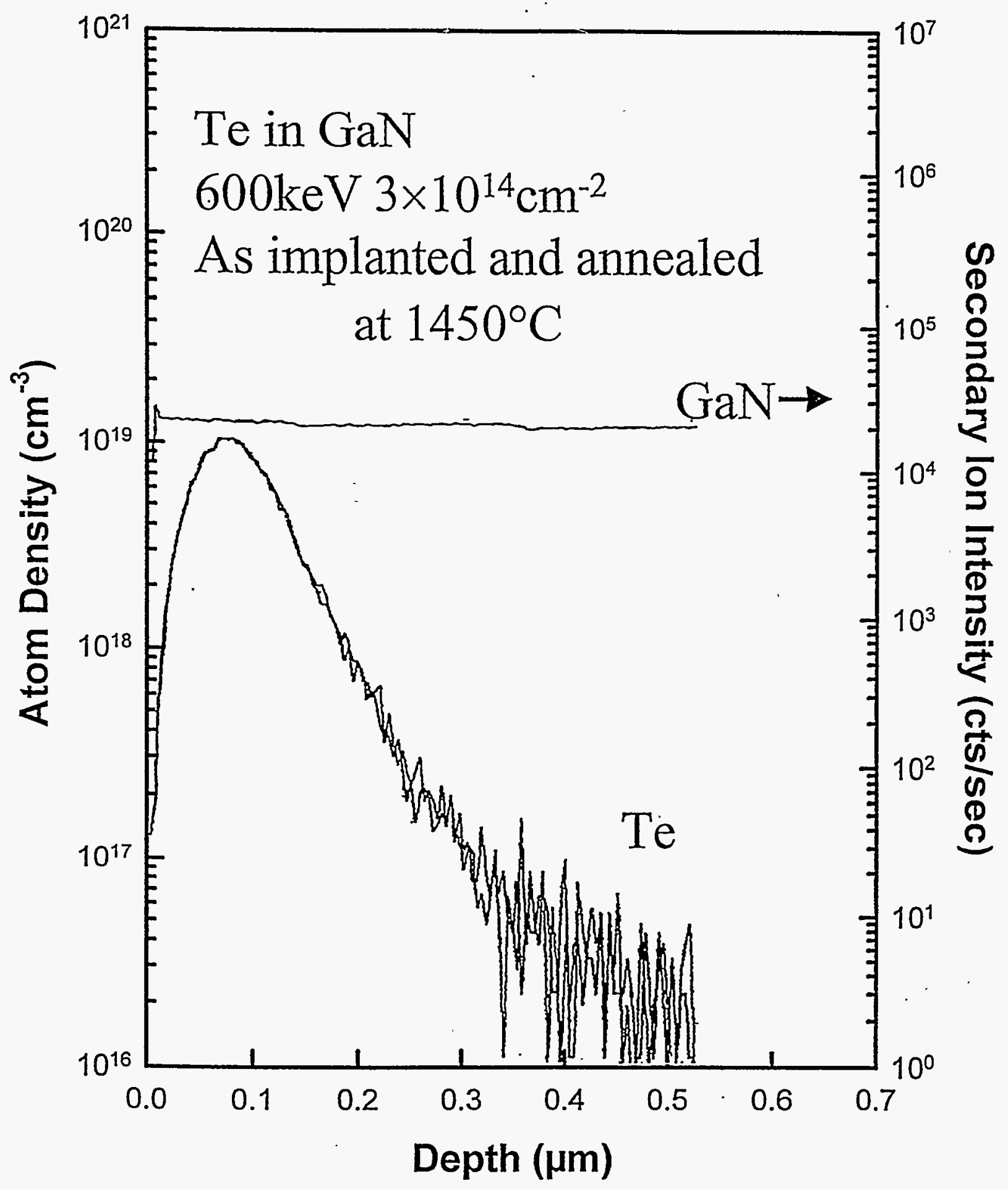

